\title{
La entrada de los gobernadores en Manila: el ceremonial y sus $\operatorname{costes}^{1}$
}

\author{
por \\ Patricio Hidalgo Nuchera \\ Universidad Autónoma de Madrid
}

Las entradas de las máximas autoridades politicas en el territorio a gobernar constituían una fiesta política, cuya intención era asegurar la lealtad de los súbditos a la corona. En este estudio analizamos, a través de la documentación generada por sus propios protagonistas, el ceremonial correspondiente a la entrada de los gobernadores en Manila y su coste económico, que superaba ampliamente el límite de los 1.000 pesos fijado en 1686.

Palabras clave: entrada; gobernador; ceremonial; fiesta política; Manila.

Dentro de las fórmulas de reconocimiento de la autoridad de los gobernantes por los gobernados, las entradas constituían el primer contacto físico entre unos y otros. Suponían un momento crucial de reconocimiento mutuo, vivificaban los compromisos y la lealtad, por lo que eran objeto de una cuidadosa preparación ${ }^{2}$.

Sin duda, la entrada es una fiesta política fundamental. El ceremonial y las decoraciones constituyen una puesta en escena deslumbrante y persuasiva, cuya principal intención es asegurar la lealtad de los súbditos ultramarinos a la monarquía hispana. Además, y como toda fiesta real, las entradas actúan como mecanismos de cohesión social, ya que los diversos grupos que componen la

${ }^{1}$ Trabajo realizado en el marco del Proyecto de Investigación "Humanistas españoles. La tradición clásica y humanística en España y América. Narrativas no oficiales, siglos XVIXVIII”, financiado por el Ministerio de Educación y Ciencia (rf. FF2012-37448-C04-01).

2 Rivero Rodríguez, 2011: 187. 
sociedad son aglutinados mediante unas ceremonias jerarquizadas que otorgan a cada miembro de la comunidad un preciso papel $^{3}$. Se puede añadir, por otra parte, que la entrada es una expresión ritualizada de la idea de la monarquía en un lugar donde el rey nunca hizo acto de presencia ${ }^{4}$.

Para hacer presente al ausente, la entrada incluía una amplia gama de procedimientos, imágenes, decoraciones, etc., que servían para glorificar a los vicarios reales. Pero toda esta parafernalia tenía un coste. ¿Cuál era aproximadamente y quiénes los encargados de asumirlo en las fiestas de recepción de gobernadores que tenían lugar en las lejanas islas Filipinas?

\section{LA FINANCIACIÓN DE LOS COSTES}

Paso previo a la realización de cualquier fiesta real era obtener la financiación correspondiente. La importancia de ello es tal que la primera noticia que hemos obtenido del recibimiento de gobernadores en Manila es relativa al gasto a realizar en tal ceremonia. En efecto, en el verano de 1608 la ciudad solicitaba a Madrid permiso para gastar en dichos recibimientos hasta 1.500 pesos y que, además, lo pudiera hacer sin esperar el visto bueno de los oficiales reales. Según se quejaba el cabildo, «no lo pasan en revista sin que V.M. dé licencia para el dicho gasto» ${ }^{5}$.

Desconocemos la respuesta, pero sí sabemos que tres años después la ciudad volvía a escribir a la corte pidiendo esta vez permiso para poder festejar a los nuevos gobernadores con fiestas y regocijos financiados por el fondo de propios de la ciudad, dando para ello como razones el respeto que todos los habitantes de Filipinas - españoles, naturales, chinos, japoneses-debían tener a su rey, encarnado en la persona de su vicario, y, no menos importante, que «lo mismo se hace en la ciudad de México en el recibimiento de los virreyes» ${ }^{6}$.

Si reputación y emulación eran los conceptos que estaban a la base de la petición de los regidores manilenses para la realización de unas solemnes celebraciones para recibir a sus nuevos gobernadores, no extraña que los 1.500 pesos presupuestados para la entrada de don Juan de Silva en 1611 se elevaran a 3.300 en la de don Alonso Fajardo de Tenza siete años más tarde;

3 Mínguez, 2004: 359-374.

${ }^{4}$ Pietschmann, 1999: 481-497.

${ }_{5}$ Cabildo secular al rey, Manila, 8 de julio de 1608, Archivo General de Indias, Sevilla (AGI), Filipinas, legajo 36, n. ${ }^{\circ} 39$. En la misma carta, la ciudad se quejaba de que lo mismo sucedía con los 300 pesos destinados al paseo del pendón real y los 400 para el Corpus Christi.

${ }^{6}$ Real cédula Aranjuez, 8 de mayo de 1612, AGI, Filipinas, legajo 340, libro 3, ff. 74v-75. 
lo que no se alteró fue, en cambio, la necesidad de su aprobación en la corte. En efecto, el procurador general de Filipinas en Madrid don Martín Castaño y Ayala se quejó en 1626 del hecho de que, en las cuentas que tomó de los propios de la ciudad de Manila el oidor don Alvaro de Mesa, éste se negó a aprobar los 3.300 pesos gastados en ella. Ante esto, el citado procurador solicitaba al rey «su real cédula para que se pasen en cuenta y que de aquí en adelante puedan hacer los dichos gastos cuando fueren gobernadores $\rangle^{7}$. El rey solicitó información al respecto tanto a la Audiencia como a los oficiales reales de Manila ${ }^{8}$.

No conocemos las respuestas de ambas autoridades, pero creemos que debió de ser negativa, ya que a mediados de 1633 el entonces procurador de la ciudad de Manila en la corte, don Juan Grau Monfalcón, volvió sobre el tema. Esta vez y bajo el argumento de «porque ha de venir a pedir a V.M. aprobación por menudo de todas las partidas que gasta», el procurador solicitaba licencia para «poder gastar de los dichos sus propios lo que fuere necesario sin tener necesidad de venir a cansar a V.M. y a su real Consejo de las Indias con cada cosa, y tarda a venir la confirmación cuatro y cinco años, y vienen a estar en abierto las cuentas». Reforzaba su argumento con que dicho permiso lo tenían «todas las ciudades de Indias y Castilla». Grau Monfalcón incluso ofrecía una alternativa a la situación por entonces en vigor: que el conocimiento de los gastos de propios de la ciudad tuviese lugar en el juicio de residencia de los gobernadores «como se hace en todas las ciudades de España y de las Indias, que ninguna viene a pedir aprobación de los gastos que hace de sus propios» ${ }^{9}$. Cinco años después el monarca permitió - mediante real cédula de 8 de diciembre de 1638- que la ciudad de Manila pudiese gastar, con la aprobación de tan sólo el gobernador o de la Audiencia, hasta 500 pesos de sus propios, pero superando este límite habría de solicitar confirmación al Consejo de Indias. Pero como antes de expedirse esta autorización la ciudad ya había gastado algunas partidas que no excedían tal cantidad, sus representantes solicitaron que fuesen aprobadas por las citadas autoridades; en Madrid no se puso reparo alguno a la petición ${ }^{10}$.

\footnotetext{
${ }^{7}$ Petición de Martín Castaño sobre recibir gobernadores, 1626, AGI, Filipinas, legajo 27, n. ${ }^{\circ} 137$, f. 739 .

${ }^{8}$ Reales cédulas Madrid, 4 de agosto de 1626, dirigidas a la Audiencia de Manila y a los oficiales reales de Filipinas respectivamente, AGI, Filipinas, legajo 340, libro 3, ff. 190v191 y 191-191v.

9 Petición del procurador de la ciudad de Manila sobre gastos de propios, 5 de julio de 1633, AGI, Filipinas, legajo 27, n. ${ }^{\circ}$ 163, ff. 935-935v.

${ }^{10}$ Real cédula Madrid, 22 de marzo de 1640, AGI, Filipinas, legajo 28, n. ${ }^{\circ}$ 53, ff. 234-234v.
} 
Los gastos en los recibimientos de gobernadores celebrados en Manila se dispararon a lo largo del siglo XVII. Las cifras aportadas por Alva Rodríguez son elocuentes al respecto:

Tabla i. Gastos en Recibimiento De Gobernadores, 1596-1690

\begin{tabular}{|l|l|c|}
\hline Año & \multicolumn{1}{|c|}{ Gobernador } & Coste en pesos \\
\hline 1596 & Francisco Tello & 830 \\
\hline 1603 & Pedro de Acuña & 508 \\
\hline 1608 & Rodrigo de Vivero & 1.550 \\
\hline 1609 & Juan de Silva & 1.840 \\
\hline 1618 & Alonso Fajardo & 3.339 \\
\hline 1625 & Fernando de Silva & 1.609 \\
\hline 1626 & Juan Niño de Tavora & 1.879 \\
\hline 1633 & Juan Cerezo de Salamanca & 2.044 \\
\hline 1635 & Sebastián Hurtado de Corcuera & 2.753 \\
\hline 1644 & Diego Fajardo & 4.233 \\
\hline 1653 & Sabiniano Manrique de Lara & 2.998 \\
\hline 1663 & Diego Salcedo & 1.886 \\
\hline 1678 & Juan de Vargas & 4.354 \\
\hline 1685 & Gabriel de Curucelaegui & 1.152 \\
\hline 1690 & Fausto Cruzat & 2.680 \\
\hline
\end{tabular}

Fuente: Alva Rodríguez, 1997: $126^{11}$.

No sólo fueron los gastos de recibimientos de gobernadores los que se dispararon en la capital de las Filipinas, sino también los relativos a todo tipo de fiestas religiosas y honras reales. Llegó un momento en que, para hacer frente al creciente déficit de las arcas municipales, la ciudad recurrió al préstamo; en concreto, llegó a tomar a censo la respetable cantidad de 8.412 pesos $^{12}$. Los regidores manilenses atisbaron la solución: incrementar el fondo de propios con rentas adicionales. Así, en 1678 consultaron al rey la

${ }^{11}$ La autora realiza el cuadro a partir de las cuentas dadas por el ayuntamiento a los oficiales reales de 1572 a 1693, conservadas en AGI, Filipinas, legajo 62.

12 Alva Rodríguez, 1997: 127. La cantidad tomada a censo, en cédulas citadas en nota 14. 
posibilidad de cobrar un peso de cada petaca, fardo o cajón que se embarcara para Acapulco, así como de todo navío que llegara a Manila a comerciar ${ }^{13}$; la medida debió de ser rechazada, ya que posteriormente la ciudad propuso con el mismo fin adscribir a sus propios dos encomiendas de indios de 1.800 tributos. Ante la gravedad de la situación financiera del cabildo manilense, en Madrid se tomaron dos medidas. La primera, permitir a los regidores buscar algún arbitrio que rentase hasta 800 pesos al año, aunque con varias condiciones: que no fuese una encomienda de indios ni afectase a la Real Hacienda; lo propusiesen después al gobernador y Audiencia de Manila, quienes a su vez lo remitirían al virrey y Audiencia de México; llevar confirmación real en el término que se le señalase; aplicarlo exclusivamente al desempeño de los censos tomados por la ciudad y, finalmente, que redimidos aquéllos cesase «esta gracia» ${ }^{14}$. La segunda medida de saneamiento financiero iba dirigida a atajar el gasto público, para lo que se limitaba a 1.000 pesos la cantidad que la ciudad del Pasig podía librar para los recibimientos de sus gobernadores y, 2.000, para las demás fiestas reales ${ }^{15}$.

¿Implicó esta política de austeridad un menoscabo del esplendor de las fiestas en general y de los recibimientos de gobernadores en particular? En absoluto, ya que la austeridad en el gasto público fue compensada con un aumento del privado. Es decir, el déficit producto de la diferencia entre el gasto real de la fiesta y la subvención municipal fue cubierto a partir de entonces por los alcaldes ordinarios en cuyo mandato tuviera lugar el evento festivo. Sin duda que ello era gravoso para dichas autoridades, pero no hay que olvidar que éstas sabían que su «gasto» era en realidad una «inversión» económica de la que esperaban, a cambio, obtener una ganancia en forma de prebendas $\mathrm{y}$ beneficios de manos de un gobernador bien agasajado y mejor obsequiado.

¿Compensaba la ganancia obtenida o querían maximizarla aún más? Es lo que nos preguntamos a raíz de la petición de la ciudad de Manila en 1753 de elevar el techo de gasto de los recibimientos de los 1.000 pesos presu-

${ }_{13}$ Cabildo secular al rey, Manila, 20 de junio de 1678, AGI, Filipinas, legajo 28, n. ${ }^{\circ}$ 15, ff. 833-840.

${ }^{14}$ Reales cédulas fechadas en Madrid a 12 de septiembre de 1686 dirigidas a la audiencia de Manila, al virrey de México y a la ciudad de Manila respectivamente, AGI, Filipinas, legajo 349, libro 6, ff. 95-96v, 96v-98v y 98v-100.

${ }_{15}$ Real cédula Madrid, 12 de septiembre de 1686, dirigida a la ciudad de Manila, AGI, Filipinas, legajo 349, libro 6, ff. 100-101. A destacar que desde 1618 las ciudades de México y Lima tenían también limitados sus gastos en los recibimientos de virreyes a 8.000 y 12.000 pesos respectivamente. Dicha disposición se halla recogida en la ley 19, título III, libro III de la Recopilación de leyes de Indias. 
puestados en 1686 a $4.000^{16}$. Examinemos con detenimiento esta cuestión, ya que los testimonios aducidos nos desvelan la inversión realizada en el ceremonial. Las razones que aducía la ciudad para dicha elevación del gasto son baladíes: que por ley las ciudades de México y Lima sólo podían gastar de sus propios 8.000 y 12.000 pesos respectivamente en el recibimiento de sus virreyes; que en Manila tenían que realizar «proporcionalmente las mismas demostraciones» en el recibimiento de sus gobernadores; que los dos alcaldes ordinarios en funciones el año que llegaba un nuevo gobernador soportaban los gastos de las entradas, pues los 500 pesos que la ciudad libraba a cada uno de ellos eran insuficientes; y, por último, que la elevación del gasto a 4.000 pesos sería «en beneficio de todo el vecindario» ${ }^{17}$. Por supuesto, los festejos y diversiones correspondientes estarían garantizados, aunque a costa de gravar aún más la Hacienda municipal.

El escrito fue pasado a informe del fiscal del Consejo de Indias, quien no sólo se percató de que la ciudad no justificaba el coste de las entradas sino que callaba que a los alcaldes ordinarios que soportaban los déficit de las entradas «procuran los gobernadores resarcirlos dándoles las mejores comisiones que se ofrecen y de alguna utilidad ${ }^{18}$. A la vista de este dictamen, los consejeros de Indias determinaron recabar un informe reservado a la Audiencia de Manila sobre la pretensión de la ciudad y los gastos realizados en los recibimientos de gobernadores ${ }^{19}$.

Para su realización, los oidores interrogaron a algunos de los que, en años anteriores, habían estado al cargo de tales ceremonias ${ }^{20}$. Declararon el marqués de Montecastro y Llanahermosa, alcalde ordinario en el momento de la llegada del gobernador Gaspar de la Torre (1739); el general don Sebastián Aramburu, que lo era a la llegada del marqués de Obando (1750), y el sargento mayor don Blas José Castrillón de Casariego, que ocupaba tal cargo a la llegada del gobernador don Pedro Manuel de Arandía (1754). Sus respuestas son muy ilustrativas: los gastos realizados habían superado los 8.000 pesos, salidos del propio caudal de los dos alcaldes ordinarios encargados del recibimiento, a excepción de los 1.000 librados por la ciudad de sus bienes de propios; las tareas del recibimiento se dividían entre los dos citados alcaldes, quienes

${ }^{16}$ Cabildo secular al rey, Manila, 18 de julio de 1753, AGI, Filipinas, legajo 189B, ramo 12.

17 Idem.

${ }^{18}$ Dictamen del fiscal del Consejo de Indias a la carta del cabildo secular de Manila, Madrid, 5 de marzo de 1755, AGI, Filipinas, legajo 189B, ramo 12.

19 Real cédula Aranjuez, 14 de mayo de 1755, AGI, Filipinas, legajo 335, libro 16, ff. 343-344.

${ }^{20}$ Audiencia de Manila al rey, Manila, 20 de julio de 1757, AGI, Filipinas, legajo 185, n. ${ }^{\circ} 18$. 
percibían para llevarlas a cabo 500 pesos cada uno. Uno de ellos se encargaba de todo lo relacionado con el recibimiento y estancia del gobernador en los extramuros de la ciudad durante el tiempo que dicha autoridad considerase necesario antes de hacer su entrada pública en la ciudad; durante ese período, entonces discrecional ${ }^{21}$, los gastos eran costeados por el citado regidor. Por su parte, el segundo alcalde ordinario se ocupaba de todo lo relativo a la composición y adorno del palacio, dotación de camas y ajuar correspondiente; y por si acaso era poco, costeaba los gastos de los tres primeros días, que a veces eran más, de comida y refrescos, dejando provisiones en la despensa para algunos meses.

Uno de los testigos, el general Aramburu, sostenía que el alcalde ocupado del recibimiento extramuros gastaba más de 4.000 pesos, mientras que el encargado de la recepción intramuros superaba los 6.000. ¿Tenían alternativa al endeudamiento? La vergüenza pública. El citado testigo así lo asevera: «porque de otra suerte se exponen a un sonroxo y nota grave porque, si se experimenta la menor falta, descompone y acarrea a el alcalde que la tiene una pesadumbre con esta novilísima ciudad» ${ }^{22}$. Castrillón, por su parte, afirmaba que si el alcalde ordinario no tenía dinero suficiente para cubrir los gastos «se verá en la precisión de buscarlo a su empeño, a trueque de no verse sonrojado». De ahí que, según Aramburu, en las elecciones de alcaldes ordinarios, si se intuía la llegada de un nuevo gobernador, «los electos admitan [estar] recelosos de estos gastos» ${ }^{23}$.

Como es bien sabido, en un informe tan importante es lo que se dice como lo que se calla. Los diferentes testigos omiten cualquier referencia a los beneficios que luego obtenían por cubrir los costes del recibimiento; asimismo, nadie habla de los gastos en el levantamiento de arquitecturas efímeras, engalanamiento de edificios públicos y privados, luminarias, fuegos artificiales. Da la impresión de que estos gastos debían de correr por cuenta de las diferentes corporaciones manilenses e incluso de la población china existente en la capital y sus alrededores.

A la par que el examen de testigos, la ciudad informó a la Audiencia del estado de sus propios, manifestando el grave menoscabo sufrido a raíz de la expulsión de los sangleyes infieles ${ }^{24} \mathrm{y}$ al incendio que hubo en el parián.

${ }^{21}$ Según el marqués de Montecastro, el gobernador De la Torre permaneció nada menos que doce días en Santa Cruz extramuros, pasando los gastos de los 3.000 pesos.

${ }^{22}$ Idem.

${ }^{23}$ Idem.

${ }^{24}$ Se refiere a la llevada a cabo por el gobernador Pedro Manuel de Arandía a mediados de 1755, AGI, Filipinas, legajo 481. Díaz-Trechuelo, 1966: 206-208. Ollé, 2008: 68. 
Una vez examinados todos los datos, la Audiencia hizo saber al monarca su posición: continuar con el libramiento de los 1.000 pesos de los propios a los alcaldes ordinarios aunque moderando los gastos, para lo que sugería, por un lado, limitar la estancia del gobernador en los extramuros de la ciudad a tres días, realizando en el tercero su entrada pública; y por otro, que el ajuar y el menaje del palacio corriesen a cargo del propio gobernador ${ }^{25}$.

A pesar de que el Consejo de Indias pidió que únicamente informara la Audiencia, aprovecharon para también hacerlo uno de sus magistrados y su presidente. El oidor don Fernando Dávila de Madrid proponía una solución distinta a la de sus colegas: elevar el techo de gasto de 1.000 a 2.000 pesos que la ciudad podía gastar de sus propios en el recibimiento de los gobernadores a condición de que a éstos se les recibiera inmediatamente en palacio y que, desde allí, dispusieran su entrada pública; y que únicamente en el caso de que su llegada a las islas fuese imprevista y hubiese que desocupar y aderezar el palacio, podría el gobernador permanecer en los extramuros el tiempo preciso, pero aun en este caso la entrada la realizaría desde palacio. Opinaba Dávila que con estos ahorros serían suficientes los 2.000 pesos, «sin desembolso de dichos alcaldes ordinarios ni pensionarse el nuevo gobernador a gratificarlos» ${ }^{26}$.

Por su parte, el gobernador Pedro Manuel de Arandía realizó, en una carta muy cáustica, una enmienda a la totalidad al dictamen de la Audiencia ${ }^{27}$. Comenzaba negando la veracidad de los gastos soportados por los dos alcaldes ordinarios encargados del recibimiento, «porque aunque se quisiera aquí gastar en profusión falta en qué, y cuanto dependa del desmán es útil de los empleados y sirvientes y no del obsequiado». Continuaba juzgando excesiva la reducción de la permanencia del nuevo gobernador en extramuros a tan sólo tres días, puesto que aquella dependía del tiempo que tardara su antecesor en abandonar el palacio y su posterior limpieza, blanqueo y adorno. No comprendía la cantidad que se decía invertida en amueblar el palacio, pues excepto la cama del gobernador, el resto era de tan ínfima calidad que aquello le parecía «un mesón de paso». Criticaba que la ciudad se hubiese quejado del gasto realizado en su recibimiento, que consideraba inexcusable y existente en todo el imperio. Finalizaba Arandía exponiendo el hecho de que la ciudad

\footnotetext{
${ }^{25}$ Audiencia de Manila al rey, Manila, 20 de julio de 1757, AGI, Filipinas, legajo 185, n. ${ }^{\circ} 18$.

${ }^{26}$ Fernando Dávila de Madrid al rey, Manila, 20 de julio de 1757, AGI, Filipinas, legajo $185,{ }^{\circ}{ }^{\circ} 18$.

${ }_{27}$ Pedro Manuel de Arandía al rey, Manila, 24 de julio de 1757, AGI, Filipinas, legajo $185,{ }^{\circ}{ }^{\circ} 18$.
} 
no concedía a su más alta autoridad política la más mínima obvención en fiesta alguna (sucesos de la familia real, luminarias, etc.), sufragándolo todo el gobernador de su propio sueldo y que, al contrario, éste remuneraba «a los alcaldes empleados en la duración de su gobierno con la nominación de general en uno de los viajes al reino de Nueva España para que, en gratitud, pueda compensar lo gastado ${ }^{28}$.

Las tres cartas fueron pasadas al fiscal del Consejo de Indias, quien, tras manifestar la importancia de la ceremonia de la entrada de un gobernante, puntualizaba que los gastos eran costeados por las ciudades de sus bienes de propios y que si los diputados se excedían de la cantidad asignada, la diferencia la asumían ellos mismos de sus propios caudales. Dicho esto, el fiscal opinaba que, sin merma alguna de la ostentación exterior, habría que moderar los gastos, para lo cual proponía que los gobernadores sólo pudieran estar y ser asistidos tres días fuera de la ciudad y otros tres dentro de ella; y en segundo lugar, que el menaje del palacio fuese un préstamo interino por tres meses, pasados los cuales debía ser restituido a sus propietarios. Pensaba el fiscal que, para estos desembolsos, se podría conceder a la ciudad de Manila el permiso de gastar hasta 2.000 pesos de sus bienes de propios ${ }^{29}$. Los consejeros de Indias se mostraron de acuerdo con el dictamen de su fiscal a excepción del techo de gasto, que consideraron dejarlo en los 1.000 pesos habituales desde 1686, o sea, 500 a cada alcalde ordinario encargado del recibimiento, con el fin de financiar exclusivamente los «gastos decentes y precisos», todo lo cual se hizo saber a la ciudad de Manila por real cédula fechada en Buen Retiro a 23 de octubre de $1759^{30}$.

Si comparamos esta cantidad con los 12.000 pesos presupuestados para Lima, los 8.000 para México o los 6.000 para Chile $^{31}$, el presupuesto de la ciudad de Manila era una cifra irrisoria. Sin duda, ello determinaba la relativa sencillez del evento y su distanciamiento del modelo virreinal. Mas hay que tener en cuenta que la cantidad gastada siempre era mayor; sabemos que en el siglo XVII la ciudad recurría a préstamos de los vecinos o de diferentes obras pías ${ }^{32}$ y que, al menos desde 1686, el déficit era cubierto por los dos alcaldes ordinarios encargados de las ceremonias de la entrada. Pero ello no

28 Idem.

29 Dictamen del fiscal del Consejo de Indias, Madrid, 29 de abril de 1759, AGI, Filipinas, legajo 185, n. $^{\circ} 18$.

30 AGI, Filipinas, legajo 343, libro 12, ff. 254-256.

31 Valenzuela Márquez, 2001: 298.

32 En 1644 la ciudad tomó un préstamo para el recibimiento de Diego Fajardo y no lo devolvió hasta tres años más tarde; y para el recibimiento de Juan de Vargas en 1678, se tomaron de diversas obras pías 5.947 pesos. Alva Rodríguez, 1997: 127. 
era un gasto a fondo perdido sino una inversión de futuro, con unos beneficios que llegaron a ser tan rentables como la concesión de títulos de general de una de las naos que hacían la carrera transpacífica.

Para finalizar, hay que señalar que el techo de gasto se hallaba duplicado a fines del siglo XVIII, aunque no podemos señalar cuándo tuvo lugar tal aumento. En efecto, el gobernador Aguilar afirmaba a fines de 1793 que la ciudad libró ese año a los dos alcaldes encargados de su recibimiento 2.000 pesos fuertes, cantidad que seguía siendo insuficiente puesto que

no bastan para la comida de un día, pues sólo el ramillete y repostería cuesta mucho más, de modo que estos desgraciados mortales tienen que suplir mucho, incomodarse más y ponerse a la censura del público sobre si cumplieron o no, teniendo a mayor abundamiento que moblar el palacio, la casa y la despensa del governador. Todo esto está aprobado por S.M. menos lo de adornar el palacio $[\ldots]^{33}$.

\section{El CEREMONial De LA ENTRADA}

La entrada de un gobernador en Manila era un rito político que mostraba la fidelidad de la ciudad a la monarquía, a la par que manifestaba a todos sus habitantes el poder y la majestad del soberano bajo cuyo dominio se encontraban. La importancia de la ceremonia de la entrada de los gobernantes en la capital de las lejanas islas Filipinas fue remarcada por el fiscal del Consejo de Indias:

porque de ella se manifiesta y se haze ver la soberanía del monarcha a quien representa, y se haze más nezesaria en las Yslas Philipinas en donde concurren tantas naziones y hazen más respetable la obstentazión. Y sería de grave perjuicio a los governadores de Manila si se les minorase esta autoridad y estilo observado con todos $[\ldots]^{34}$.

Hasta el presente no se ha realizado estudio alguno sobre las ceremonias de recibimiento de gobernadores en Manila. Para elaborar el presente nos hemos basado en los datos de las entradas efectuadas por Juan de Silva (1609) ${ }^{35}$,

${ }^{33}$ Rafael María de Aguilar y Ponce de León a su amigo Jacinto Sánchez Torado, Manila, 4 de diciembre de 1793, transcrita en Retana, 1906, vol. I: 431-432.

${ }_{34}$ Dictamen del fiscal del Consejo de Indias, Madrid, 29 de abril de 1759, AGI, Filipinas, legajo 185, n. $^{\circ} 18$.

${ }_{35}$ Petición de la ciudad de Manila sobre recibir gobernadores, Manila, 20 de junio de 1611, AGI, Filipinas, legajo 27, n. ${ }^{\circ}$ 83, ff. 553-553v. Real cédula San Lorenzo, 10 de julio de 1611, AGI, Filipinas, legajo 340, libro 3, ff. 64-65. 
Alonso Fajardo de Tenza (1618) ${ }^{36}$, Domingo Zabalburu y Echeverri (1701) ${ }^{37}$, Fernando Manuel de Bustillo Bustamante y Rueda (1717) ${ }^{38}$, Toribio José de Cosío y Campo, marqués de Torre Campo (1721) ${ }^{39}$, Fernando de Valdés Tamón (1729) ${ }^{40}$, Gaspar Antonio de la Torre (1739) ${ }^{41}$, fray Juan de Arechederra (1745), obispo de Nueva Segovia, interino ${ }^{42}$, Pedro Manuel de Arandía y Santisteban (1754) ${ }^{43}$, Miguel de Ezpeleta (1759), obispo de Cebú, interino ${ }^{44}$, Manuel Antonio Rojo del Río y Vieyra (1761), arzobispo de Manila, interino ${ }^{45}$, José Raón $(1765)^{46}$, Rafael María de Aguilar y Ponce de León (1793) ${ }^{47}$ y Mariano Ricafort $(1825)^{48}$. Datos, a veces muy parcos ${ }^{49}$, a los que hay que

${ }^{36}$ Audiencia de Manila al rey, Manila, 10 de diciembre de 1619, AGI, Filipinas, legajo 20, ramo 13, n. $^{\circ} 94$.

${ }^{37}$ Zabalburu al rey, Manila, 8 de junio de 1702, AGI, Filipinas, legajo 126, n. ${ }^{\circ} 7$.

${ }^{38}$ Bustillo al rey, Manila, 16 de agosto de 1717, AGI, Filipinas, legajo 131, n. ${ }^{\circ} 14 \mathrm{y}$ legajo 137, n. $^{\circ} 2$.

39 Torre Campo al rey, Manila, 25 de julio de 1721, AGI, Filipinas, legajo 133, n. ${ }^{\circ} 29$ (duplicado en Filipinas, legajo 139, n. ${ }^{\circ} 1$ ).

${ }^{40}$ Valdés Tamón a José Patiño, Manila, 12 de febrero de 1730, AGI, Filipinas, legajo 142, n. ${ }^{\circ} 12$.

${ }^{41}$ De la Torre al rey, Manila, 13 de junio de 1740, AGI, Filipinas, legajo 149, n. 25.

${ }^{42}$ Arechederra al rey, Manila, 29 de septiembre de 1745 y 2 de junio de 1746, AGI, Filipinas, legajo 449, n. $^{\circ} 5$.

${ }^{43}$ Arandía al rey, Manila 19 de julio de 1754, AGI, Filipinas, legajo 386, n. ${ }^{\circ} 10$.

${ }^{44}$ Ezpeleta al rey, Manila, 12 y 15 de julio de 1759, AGI, Filipinas, legajo 388, n. ${ }^{\circ} 3$.

${ }^{45}$ Rojo al rey, Manila, 17 de julio de 1761, AGI, Filipinas, legajo 388, n. ${ }^{\circ} 39$.

${ }^{46}$ Raón al rey, Manila, 27 de agosto de 1765, AGI, Filipinas, legajo 388, n. ${ }^{\circ} 83$ (duplicado en Filipinas, legajo 388, n. ${ }^{\circ} 84$ ).

47 Aguilar a don Pedro de Acuña, secretario de Estado y del despacho de Gracia y Justicia de España e Indias, Manila, 30 de octubre de 1793, AGI, Filipinas, legajo 389, n. ${ }^{\circ} 25$. Aguilar a su amigo Jacinto Sánchez Torado, Manila, 4 de diciembre de 1793, transcrita en Retana, 1906, vol. I: 431-432. Destaca esta carta por el lenguaje franco de su autor, quien revela que tuvo que «soportar» un ceremonial al que califica de «fastidioso, pesado e incómodo».

48 Ricafort al secretario de Estado y del despacho universal de Estado, Manila, 27 de octubre de 1825, Archivo del Ministerio de Asuntos Exteriores, Madrid, H 2955. Mayor información ofrece Pérez de Uriondo, 1825.

49 Algunos de los gobernadores citados, como Ezpeleta, Raón, Aguilar y Ricafort, se limitan a notificar el día de su toma de posesión, sin ofrecer más noticias sobre las ceremonias de sus respectivas entradas. De comunicar dicho suceso a Madrid tenían obligación todos los gobernadores indianos. La medida se remonta al 24 de abril de 1651, cuando un decreto de la Cámara ordenó que «en todos los títulos de goviernos o presidencias» se incluyese una cláusula advirtiendo a los provistos en tales empleos de la obligación de enviar testimonio del día en que tomaren posesión, so pena de que pasados ocho años los presidentes y cinco o tres los corregidores se proveerían de nuevo tales empleos; asimismo y para evitar omisiones, debían comunicarlo asimismo los oficiales reales. La orden está recogida como auto acordado $\mathrm{n}^{\circ}$ CLX de León Pinelo, 1658. Su inobservancia llevó a la corona a multar a los electos y a los oficiales reales que no cumplieran con su deber, a la par que ordenaba a estos últimos no 
sumar la información aportada en la documentación utilizada en la primera parte de este trabajo.

Del análisis de la documentación relativa a las entradas de los gobernadores citados hemos observado toda una serie de actos que podríamos agrupar en dos grandes etapas, cada una de ellas, como acabamos de ver, a cargo de un alcalde ordinario.

$1^{\text {a }}$ etapa. El ceremonial privado de la víspera
a. Alojamiento en extramuros
b. Cumplimientos oficiales
c. Juramento y toma de posesión

$2^{\mathrm{a}}$ etapa. El ceremonial de la recepción pública

a. La renovación del juramento ante una de las puertas de la muralla

b. La entrada en la ciudad

c. Te Deum en el templo mayor

d. Actos en palacio

e. Regocijos oficiales y festejos espontáneos

¿Realizaron todos los gobernadores citados íntegramente este complejo ritual? Creemos que sí, aunque no siempre lo confirma la documentación consultada. Así, ésta recoge el ceremonial privado y la entrada pública de Bustillo Bustamante, De la Torre, Aguilar y Ricafort (la relativa a Raón sólo indica que las llevó a cabo); la de Zabalburu recoge la renovación del juramento, mientras que la del resto únicamente informa del ceremonial privado.

$1^{a}$ etapa. El ceremonial privado de la víspera

La entrada de los gobernadores en Manila intentaba emular el ceremonial de la corte virreinal novohispana, aunque el rango de la autoridad vicaria filipina y la situación económica de las islas hacían que la primera fuera tan sólo un pálido reflejo de la segunda.

Desde la cubierta del galeón que lo transportaba, el nuevo vicario real podría observar cómo la ciudad amurallada de Manila, conocida como Intramu-

abonar los salarios de los presidentes, gobernadores, corregidores y alcaldes mayores sin que primero les constase haber remitido el citado testimonio al Consejo de Indias. Así lo consignaba la real cédula Madrid, 6 de marzo de 1720, obedecida por el marqués de Torre Campo en el pueblo de Rosario, extramuros de Manila, el día 28 de julio de 1721, cuatro días después de su toma de posesión, AGI, Filipinas, legajo 133, n. ${ }^{\circ} 29$. 
ros, estaba edificada en la orilla izquierda de la desembocadura del río Pasig, rodeada de una muralla con foso, contrafoso y diversos baluartes defensivos, destacando en el extremo noroccidental una ciudadela militar conocida como Real Fuerza de Santiago. Y, a la otra orilla del río, unido a Intramuros por un puente de piedra, se expandía el populoso arrabal de Binondo, importante centro comercial de la región.

Una vez fondeado el navío frente al puerto de Cavite, se trasladaba a él una serie de comisionados de la ciudad para cumplimentar a la nueva autoridad y acordar su desembarco. Este no siempre se producía inmediatamente. En el caso de Aguilar (1793) y Ricafort (1825), tanto la llegada de las comisiones como el desembarco tuvieron lugar al día siguiente, seguramente debido a la hora de llegada del navío, del que sólo sabemos que el de Aguilar fondeó a las 3 de la tarde.

Acompañados por los citados comisionados, el gobernador embarcaba en una falúa rumbo a tierra firme. Una vez en ella, el ceremonial recrea un elemento presente en las recepciones de los virreyes de México y Lima, quienes permanecían varios días fuera de la capital antes de entrar oficialmente en ella. Además de la emulación, es posible que en ello jugaran razones de índole más práctica. Como es sabido, en el ritual político del recibimiento no podían faltar arcos triunfales, colgaduras, adornos, festejos, etc., y bien podía ocurrir que cuando arribara el galeón con el nuevo vicario real a bordo dichos preparativos no estuvieran concluidos. Así sucedió en 1619 a la llegada de Alonso Fajardo, a quien por dicha razón la ciudad le rogó que permaneciera en Cavite algunos días. Fajardo accedió y quedó en el puerto un tiempo -no sabemos cuánto- pero sí que, aunque no hubo motivo que le obligara a ello,

[...] se vino calladamente la mañana del mismo día que para por la tarde estava aplazado su rezivimiento en público; y entrando por un postigo de junto a palazio, sólo sirvieron los arcos y otras prevençiones que estaban hechas, de haverse gastado en valde mucha cantidad de pesos; al punto que entró se fue a la Real Audiençia vestido de camino para que le rezibiera, con tanta prisa que se dejó los títulos en un escriptorcillo, por el qual embió y los sacó dél estando en el Acuerdo $[\ldots]^{50}$.

No sólo eran los pesos gastados en balde, sino que la no realización del rito iba en detrimento de lo que simbolizaba. Más que los gastos importaba el artefacto político que daba a entender la lealtad de la lejana gobernación a la monarquía. Lo mismo sucedió en 1825: aun a bordo del navío, el gobernador

50 Audiencia de Manila al rey, Manila, 10 de diciembre de 1619, AGI, Filipinas, legajo 20 , ramo 13, n. $^{\circ} 94$. 
Ricafort manifestó a los comisionados que fueron a recibirle su deseo de saltar a tierra «sin ruido ni aparato», y que no se hiciesen gastos en su recibimiento. Es posible que actuase así pensando en los costes de la ceremonia que tendría lugar poco tiempo después: la entrada del retrato de Fernando VII del cual él era el portador ${ }^{51}$. Sin embargo, el Ayuntamiento le respondió que hacía mucho tiempo que estaban dispuestos los preparativos. Sin duda, los regidores eran conscientes de la importancia del ritual para legitimar la autoridad colonial.

¿Dónde se alojaba y durante cuánto tiempo en los extramuros de la ciudad? La respuesta a la segunda cuestión ya la conocemos: hasta 1759 quedaba al arbitrio del gobernador entrante (recordemos que la estancia extramuros de Gaspar de la Torre fue de doce días) mientras su antecesor abandonaba el palacio y éste se blanqueaba, limpiaba y aderezaba para el nuevo inquilino. Pero los gastos que ello ocasionaba al alcalde ordinario encargado del recibimiento extramuros llevaron a que en ese año se limitara la estancia a sólo tres días.

En cuanto al lugar del alojamiento, la documentación nos revela que no siempre fue el mismo. Así, Bustillo Bustamante (1717), el marqués de Torre Campo (1721) y el citado De la Torre (1739) fueron alojados en el llamado «sitio del Rosario»; Aguilar (1793) lo fue en la isla de la Convalecencia, situada en el cauce del Pasig, cerca del arrabal de San Miguel; y Ricafort (1825), por su parte, estuvo hospedado en el barrio de Binondo. ¿A quién pertenecían las casas que servían de hospedaje a tan regios invitados? En este asunto, la documentación es parca; tan sólo sabemos que Bustillo Bustamante se alojó «en las casas que fueron de la morada del general Miguel Rodríguez», mientras que Ricafort lo hizo en la casa de la Administración de la Renta del Vino. Si bien en este último caso es un edificio público u oficial, en el primero se trata de uno privado; y aunque la documentación calla quién en ese momento la habitaba, no podemos rechazar la hipótesis de que fuese propiedad de algún magnate de la élite local que quisiera mostrar con ello un signo de distinción $\mathrm{y}$, por supuesto, realizar una inversión de futuro.

Durante los tres días que los gobernadores pasaban en las residencias radicadas en las afueras de Manila tenían lugar tres actos ceremoniales: cumplimientos, juramento y toma de posesión. Comenzando por los primeros, podemos tomar como referencia los efectuados con motivo de la llegada del gobernador Aguilar en 1793. En primer lugar recibe bajo dosel los reglamentarios saludos de los miembros de la audiencia, ciudad, cabildo eclesiástico, consulado, diputación de comercio, capitanes de embarcaciones extranjeras fondeadas en Manila, oficiales de juzgados varios, estado mayor de la plaza y oficialidad;

\footnotetext{
${ }^{51}$ Moreno Garbayo, 1977.
} 
su esposa, en otra habitación, repetía las mismas ceremonias ${ }^{52}$. Luego, y a lo largo de tres días, tienen lugar bailes, música, iluminaciones, obsequios, comidas y cenas, etc. ¿Cuál es el significado de estos cumplidos, especialmente los ofrecidos por individuos particulares? Antes que nada hay que indicar que no eran exclusivos de Manila, sino que tenían lugar igualmente en las cortes virreinales de México y Lima. A ellos, como acabamos de ver, acudía la élite social manilense acuciada por el deseo de establecer con el nuevo vicario real el papel de actores esenciales del sistema de poder a nivel local ${ }^{53}$.

Con respecto a los banquetes, ¿quién o quiénes los financiaban? La documentación consultada no señala nada al respecto, por lo que lo más lógico sería computarlos al alcalde ordinario encargado del recibimiento extramuros. Pero no podemos desechar que también participaran en ello otros regidores e incluso miembros de la élite local, deseosos de realizar un lucimiento personal frente a sus pares y a la nueva autoridad. Si esto fuera así, podríamos afirmar -siguiendo el modélico estudio de antropología del ritual de Jaime Valenzuela- que estamos frente a una «inversión simbólica» de la élite local (individual e institucional) a partir de la cual alojamiento, banquetes y regalos pueden ser vistos bajo la categoría de reciprocidad del intercambio ${ }^{54}$.

Un segundo acto que tenía lugar durante la víspera de la entrada pública a la ciudad era el juramento y la toma de posesión de los cargos para los que la nueva autoridad vicarial había sido nombrada. En este tema, la documentación consultada nos muestra varias alternativas. En unos casos, todo el acto se realizó durante la celebración de un solo Real Acuerdo extraordinario de la Audiencia manilense: así lo llevaron a cabo Bustillo Bustamante (31 de julio de 1717), el marqués de Torre Campo (24 de julio de 1721), Arandía (19 de julio de 1754) y Raón (6 de julio de 1765). En otros, en un primer Real Acuerdo extraordinario sus miembros obedecieron el título de presidente de la Audiencia para, a continuación, comunicar al electo que podía pasar a tomar posesión en un segundo Acuerdo cuando lo considerase oportuno. Fue el caso de Valdés Tamón (1 y 14 de agosto de 1729) y De la Torre (5 y 7 de septiembre de 1739). Por último, la documentación relativa a Aguilar y Ricafort nos revela que el juramento y la toma de posesión tuvieron lugar el segundo día de sus respectivas estancias en extramuros ${ }^{55}$, señalando que

${ }^{52}$ El relato de Aguilar es el único de un gobernador que recoge el papel de su esposa en el ceremonial del recibimiento.

53 Valenzuela Márquez, 2001: 304.

54 Ibidem: 307.

${ }^{55}$ Lo mismo sucedía en el México dieciochesco. Véase al respecto el relato de Panes, 1994: 107-112. 
ambos entraron de forma particular en Manila y que privadamente, en Real Acuerdo extraordinario de la Audiencia, tomaron posesión de su presidencia, el 31 de agosto de 1793 el primero y el 12 de octubre de 1825 el segundo.

Nos imaginamos que esta entrada privada, efectuada «de incógnito» desde el lugar extramuros donde se alojaban los gobernadores electos antes de la entrada pública hasta la Audiencia donde tenía lugar la ceremonia oficial del juramento y toma de posesión, la harían también el resto de los gobernadores filipinos. Sin embargo, sabemos que en el caso de Bustillo Bustamante (1717) no sucedió así, ya que el Real Acuerdo se celebró en el pueblo de Rosario donde aquél se alojaba «por no haber dado lugar a otra cosa lo riguroso del tiempo de las lluvias».

La ceremonia del juramento y toma de posesión era un acto solemne. Aunque la documentación señala algunas variantes, el mecanismo habitual era el siguiente. En un Real Acuerdo extraordinario, el escribano de cámara lee el título presentado por el nuevo vicario real de presidente de la Audiencia; tras su lectura, los oidores puestos en pie lo toman, besan y ponen sobre sus cabezas como «carta y provisión real de su rey y señor natural». A continuación, el oidor decano toma juramento y pleito homenaje a la nueva autoridad real. La escena tiene lugar ante la mesa del Real Acuerdo, sobre la que reposan un crucifijo, un misal abierto y una fuente donde se hallan depositadas las llaves de la ciudad. Poniendo la mano derecha sobre los santos Evangelios (y, en caso de ser miembro de la orden de Santiago o de Calatrava, la izquierda sobre la cruz bordada en su pecho), el nuevo vicario real jura por Dios y la santa cruz usar bien de sus cargos de gobernador, capitán general y presidente de la Audiencia, guardar las leyes del reino y las ordenanzas del citado tribunal, así como atender a la defensa del territorio. En unos casos, la documentación señala que el juramento es el «predefinido»y, en otros, que se realiza según el «formulario general» que el rey tiene dado. Sólo en el caso de Bustillo Bustamante (1717) se registra la fórmula, que transcribimos a continuación por su rareza e importancia (los signos de interrogación son míos):

¿Jura V. señoría por Dios nuestro señor a fuer de cavallero e hijodalgo y a la Cruz y a estos sanctos evangelios como cathólico y fiel christiano, bueno y honrado caballero hijodalgo, y haze pleito omenage según fueros de Castilla de que guardará y defenderá dicha ciudad de Manila, plazas, presidios y provincias que domina en ellas y las que de nuebo se conquistaren por el dicho nuestro señor, que Dios guarde de qualesquier enemigos que las quieran ofender, y que tendrá a todas estas Yslas, sus presidios en buena guardia y fiel custodia en su real nombre y debajo de su real obediencia sin rendirlas ni entregarlas si no fuere a la persona que su Magestad ordenare, cumpliendo en todo su real voluntad? ¿Y asimesmo jura V. señoría de guardar esta ciudad y a las demás 
villas y lugares de este reino sus fueros y privilegios, exempciones y jurisdicción que por la cathólica y real persona le son concedidas, y que en todo hará lo que deve y es obligado? A que respondió dicho señor mariscal Don Fernando Manuel de Bustamante Bustillo y Rueda: Sí juro y amén.

Tras jurar, el nuevo presidente de la Audiencia recibe el bastón de mando y toma su asiento preferente entre los oidores. Por último, el canciller, acompañado de dos magistrados, sale de la habitación en busca del sello real usado en la Audiencia manilense; una vez en la sala, lo entrega al presidente, quien de pie lo besa y pone sobre su cabeza con toda veneración; finalmente, lo entrega de nuevo al canciller para devolverlo a su lugar. Quedaba de esta manera la nueva autoridad real en pleno ejercicio de sus funciones.

Como hemos visto, la ceremonia del juramento y toma de posesión tenía lugar en la Audiencia y sólo ante sus miembros. En cambio, los representantes de la ciudad asistirán posteriormente, exactamente al inicio de la entrada pública, a una ceremonia similar, en la cual el vicario real renovará su juramento ante ellos. Sin embargo hay una excepción en la que oidores y regidores compartían el mismo espacio: me refiero a la toma de posesión de los gobernadores interinos, quienes no realizaban entrada pública. En los casos de Arechederra (Real Acuerdo extraordinario de 21 de septiembre de 1745) y Rojo del Río (19 de abril de 1761), tras la toma del juramento por parte de la Audiencia entró en la sala la corporación municipal, la cual, después de recibir el respectivo juramento y pleito homenaje, entregó las llaves de la ciudad a la nueva autoridad. En el caso de Arechederra, la documentación señala que posteriormente entró en la sala del Real Acuerdo el sargento mayor y gobernador del tercio de Filipinas, quien también recibió pleito homenaje del susodicho y juramento de que guardaría y defendería la plaza. Del resto de los gobernadores analizados, sólo de Bustillo Bustamante tenemos constancia de que la ciudad compartiera espacio con la Audiencia, en este caso porque la lluvia impidió la entrada pública. En efecto, mientras el juramento ante la Audiencia tuvo lugar a las 4 de la tarde en el Real Acuerdo extraordinario celebrado en el sitio del Rosario el día 31 de julio de 1717, una hora después le tocó el turno a la ciudad; al entrar sus miembros en la sala del Acuerdo, Bustillo Bustamante, acompañado del oidor decano y el fiscal, se retiró a una pieza contigua; entonces los capitulares obedecieron su título de nombramiento, poniéndolo sobre sus cabezas como «cartas de su rey y señor natural»; a continuación, los regidores pasaron a la habitación donde se hallaba la nueva autoridad real para, por medio del escribano mayor, tomarle juramento y pleito homenaje y, por último, entregarle las llaves de la ciudad. 


\section{$2^{a}$ etapa. El ceremonial de la recepción pública}

La segunda etapa comprendía el conjunto de liturgias civiles y religiosas de carácter público que rodeaban la entrada del gobernador y a través de las cuales la «presencia» del representante del monarca en el reino se reforzaba en el imaginario colectivo ${ }^{56}$. De la lectura de diferentes entradas de gobernadores en Manila podemos colegir la existencia de hasta cinco fases consecutivas, aunque no todas presentes en los diferentes textos analizados: la renovación del juramento en una de las puertas de la muralla ${ }^{57}$, la entrada a la ciudad, el ingreso en la catedral, los actos en palacio y, por último, los festejos oficiales.

Antes de pasar a analizar cada una de las citadas fases conviene señalar que el lugar donde se realizaban estas ceremonias era la calle, la vía pública por la que transitaría luego el cortejo hasta la plaza de armas, lugar donde se alzaban los tres edificios más simbólicos de la ciudad: la catedral, el palacio real y las casas del cabildo. Tales calles se engalanaban con arcos triunfales, tapices, mantones de Manila..., intentando emular el modelo virreinal novohispano. La documentación consultada no informa sobre los materiales de la arquitectura efímera (adobe, madera), la existencia de cartelas alegóricas, si el cortejo portaba las armas del rey y las del nuevo gobernador, si desfilaba el blasón de la ciudad, etc. Sin duda, razones financieras explican que dicha arquitectura fuera más pobre que la de las cortes virreinales, aunque no menos vistosas por el exótico estilo chinesco, pero no cabe duda de que los arcos funcionaban como un apoyo singular al evento y como un signo claro de la estrategia de reproducción cultural que marcaba esta liturgia ${ }^{58}$. Sin duda, aunque toscos, los arcos imponían una majestuosidad, no por sus adornos ni riqueza, sino más bien por su sola presencia.

\section{La renovación del juramento}

Frente a esta decoración teatral y rodeado de todas las autoridades y notables de la ciudad que lo habían acompañado desde su hospedaje extramu-

56 Valenzuela Márquez, 2001: 307.

57 En la muralla que rodeaba intramuros se abría una serie de puertas. Por la llamada Real, situada en el lienzo meridional, tenían lugar las entradas solemnes de gobernadores y arzobispos; sin embargo, después de la toma de Manila por los ingleses en 1762, dicha puerta se trasladó de lugar y se estrechó mucho, lo que motivó que las entradas públicas de las autoridades citadas comenzaran a realizarse por la puerta del parián, situada en el lienzo oriental de la muralla. Buzeta y Bravo, 1850, véase la voz «Manila».

58 Valenzuela Márquez, 2001: 310. 
ros, el nuevo gobernador se aprestaba a la realización de la ceremonia de la renovación del juramento. Seguidamente vamos a analizar las llevadas a cabo por Zabalburu ( 8 de septiembre de 1701), Bustillo Bustamante (24 de agosto de 1717), De la Torre (7 de septiembre de 1739), Raón (8 de julio de 1765), Aguilar (2 de septiembre de 1793) y Ricafort (14 de octubre de 1825). ¿Cuánto tiempo había transcurrido desde sus respectivas tomas de posesión? Por los datos de que disponemos, hasta mediados del siglo XVIII parece que el tiempo entre ambas ceremonias no estaba tasado. Así, en el caso de Bustillo Bustamante transcurrieron veinticuatro días entre una y otra, mientras que De la Torre efectuó ambas en la misma jornada; en cambio, Raón, Aguilar y Ricafort renovaron el juramento dos días después de sus respectivas tomas de posesión y, en el caso de los dos últimos, sabemos incluso que las llevaron a cabo el segundo día de su estancia privada en extramuros (recordemos que en 1759 ésta se redujo a tan sólo tres días). Y aunque sólo contamos con dos muestras, podría inferirse que tal lapso se convirtió en norma desde entonces.

Las ceremonias de renovación del juramento de Zabalburu, Bustillo Bustamante y De la Torre fueron, aunque con pequeñas diferencias, muy similares. Exponemos a continuación la que realizó el último de ellos en 1739 . a) Parte de su alojamiento en el sitio de Rosario extramuros a caballo hacia la puerta Real, acompañado de los ministros de la Audiencia, regidores y vecindario. b) Frente a dicha puerta se apea de su cabalgadura y sube a un tablado con los capitulares de la ciudad. c) El alférez real obedece el título real de nombramiento del gobernador, besándolo y poniéndolo sobre su cabeza. d) A continuación, el escribano mayor del cabildo le toma el juramento. En el caso de Zabalburu la documentación señala que dicho funcionario le pidió que pusiese una mano sobre su pecho -era caballero de Santiago- y otra sobre el misal dispuesto sobre una mesa. e) Una vez realizado «en la forma acostumbrada» ${ }^{59}$, uno de los alcaldes ordinarios le hace entrega de las llaves de la ciudad, que según los datos relativos a Zabalburu se encontraban depositadas en la mesa junto al misal. f) Admitidas por el gobernador «en demostración y acto de posesión», las entrega a su vez al maestre de campo, ordenando que se abriese la puerta de entrada a la ciudad.

Más parca es la documentación con respecto a Aguilar (1793): desde su morada en la isla de la Convalecencia llega a la puerta del parián, donde

${ }^{59} \mathrm{La}$ documentación nos ofrece tan sólo la fórmula usada por Zabalburu (1701), casi idéntica a la empleada por Bustillo Bustamante en su entrada privada (1717). Así, el nuevo gobernador juraba la defensa de la ciudad y de las islas, gobernar de acuerdo con la ley y los preceptos divinos en beneficio de la monarquía y del reino y, por último, respetar los privilegios de la ciudad. 
jura la defensa de la plaza. En cambio, en la entrada de Ricafort (1825) no se alude a juramento alguno. Probablemente la razón radique en que dicha ceremonia se hubiera subsumido en la de la toma de posesión tenida durante el segundo día de su estancia en extramuros; hasta entonces eran dos ceremonias independientes, tal como realizaron De la Torre (1739) y Aguilar (1793).

Como puede comprobarse, la fórmula de la renovación del juramento seguía las pautas de la que realizaban los virreyes y el propio monarca antes de su entrada a las ciudades principales. La documentación consultada para el caso de Manila señala, aunque bien cierto que sólo en el caso de Zabalburu, la presencia en esta ceremonia de lo religioso: un misal abierto sobre una mesa, aunque omite si el gobernador se arrodillaba, si posaba sus manos sobre un misal mientras leía en voz alta el texto del juramento, si había algún crucifijo sobre la mesa, etc., signos de sumisión a la voluntad divina. La solemnidad del acto debía de producir una emoción colectiva que, lejos de agotarse en ese momento, se iba a prolongar a través del próximo rito: la entrada a la ciudad.

La entrada

Posteriormente a la ceremonia descrita, el gobernador volvía a montar en su caballo para proceder a realizar el rito de la entrada a la ciudad bajo la puerta -transformada efímeramente en arco triunfal- ante la cual había tenido lugar la renovación del juramento.

Seguido de un cortejo compuesto de los principales actores políticos, la nueva autoridad avanzaba por las calles engalanadas. Por supuesto, el cortejo tenía una rígida formación protocolaria en la que cada cual manifestaba su posición social; de tal manera que salirse del protocolo era romper con dicho orden, elevándose la consecuente queja del sector agraviado. Sabido es que las disputas protocolarias estaban a la orden del día en las sociedades de Antiguo Régimen, y las entradas de gobernadores no eran una excepción. En efecto, conocemos la ocurrida con motivo de la entrada del gobernador don Juan de Silva en Manila el año de 1609.

Según los representantes de la ciudad, cuando un gobernador llegaba a Manila a tomar posesión del cargo era costumbre que ellos salieran a recibirle «en cuerpo de ciudad». Sin embargo, en el caso de Silva la Audiencia acordó salir conjuntamente con la ciudad. El problema surgió cuando en las casas reales los oidores ordenaron a los capitulares marchar delante del escribano de cámara y del relator de la Audiencia. Menoscabada su preeminencia, los regidores se negaron a ocupar el sitio señalado, siendo apresados entonces por 
desacato ${ }^{60}$. Inmediatamente, la queja de la ciudad llegó a Madrid, y con ella su solicitud de que, dado que sus componentes servían con armas y caballos en defensa de las islas, no fuesen preteridos por el escribano de cámara ni por el relator y, lo que es más importante para conocer el ceremonial llevado a cabo hasta entonces, «que cuando los gobernadores fueren al cabildo, les reciba y entregue las llaves, tomándole el pleito homenaje que se acostumbra y debe hacer, y se asiente en el libro de dicho cabildo ${ }^{61}$. En Madrid, el Consejo de Indias fue salomónico: en cuanto a la preferencia, se ordenó a la Audiencia guardar la cédula «que trata de esto» ${ }^{62}$ y que, conforme a ella, no permitir que los escribanos de cámara ni el relator tuviesen primacía sobre la ciudad, «pues no son cuerpos de Audiencia»; y en cuanto al ceremonial, se pidió a los miembros de esta última una información sobre la costumbre guardada en los recibimientos anteriores y lo realizado en concreto en el de don Juan de Silva para, con todos los elementos de juicio, tomar la decisión correspondiente ${ }^{63}$.

Volviendo a la ceremonia de la entrada de los gobernadores filipinos, una vez traspasada la puerta el cortejo, reproduciendo el orden corporativoinstitucional de la sociedad, se dirigía a la catedral. Según el documento que relata la entrada de Ricafort (1825), por el camino había innumerables arcos vistosos, muchos aderezados al gusto asiático, una multitud de coches de gala precedían al suyo, las tropas estaban apostadas a lo largo de la carrera y había un gran gentío en las calles, «testimonio del aprecio» con que miraban al vicario del rey. En cambio, ni la documentación referente a dicho gobernador ni a ningún otro alude a dos elementos que sabemos se utilizaban en las entradas reales y virreinales: el pendón real, que como símbolo real precedía los desfiles, y el palio. Si bien este último estaba prohibido por ley a los virreyes ${ }^{64}$, pues era exclusividad del rey usarlo en sus entradas, extraña

${ }^{60}$ Petición de la ciudad de Manila sobre recibir gobernadores, Manila, 20 de junio de 1611, AGI, Filipinas, legajo 27, n. ${ }^{\circ} 83$, ff. 553-553v.

${ }^{61}$ Real cédula San Lorenzo, 10 de julio de 1611, AGI, Filipinas, legajo 340, libro 3, ff. 64-65.

${ }^{62}$ Se debe de referir a una de las refundidas en la ley 37 , título XV, libro III de la $R e$ copilación de leyes de Indias, que ordena que: «En los actos públicos de honras de personas reales y otros semejantes donde asistieren el virrey, Real Audiencia y cabildo de la ciudad, vaya el cabildo delante e inmediato a la Real Audiencia [...]». Esta ley recoge mandatos de 1617,1631 y 1637.

${ }^{63}$ Real cédula de 10 de julio de 1611 citada.

${ }^{64}$ Así lo ordena la ley 19, título III, libro III de la Recopilación de leyes de Indias. A pesar de ello, en Lima se siguió usando «porque siendo costumbre tan antigua no se han conformado en innovarla aquellos regidores por no minorar el obsequio a los virreyes, ni atreverse ninguno a ser el primero en abolirla». Véase Juan y Ulloa, 1978, parte segunda, libro I, capítulo IV: 61 . 
la ausencia del primero, a menos que simplemente se deba a que su presencia no fue recogida en la documentación consultada.

Del Te Deum en el templo mayor a los actos en palacio

Una vez llegado a la plaza mayor, cuyos edificios también estaban decorados con todo tipo de colgaduras, el solemne cortejo ingresaba en la catedral, en cuya puerta era recibido por el obispo y el cabildo catedralicio en pleno. Y una vez acomodados en el presbiterio, se procedía a cantar el himno litúrgico del Te Deum en acción de gracias. Con esta ceremonia el gobernador coronaba la ligazón que había establecido entre el cumplimiento de su cargo y la responsabilidad ante Dios. Ahora él se «cargaba» de sacralidad y el Te Deum celebrado por su nombramiento, con la solemnidad correspondiente, podía ser eventualmente visto o sentido por la comunidad como una suerte de "consagración» ${ }^{65}$. Conocemos algunos pocos datos de cómo se desarrollaba el ingreso en el primer templo de la ciudad. En el caso de Aguilar (1793), el arzobispo se puso a su derecha y le dio posesión de su silla de vicepatrono; $y$ en el de Ricafort (1825), éste fue recibido en la puerta del templo mayor por el cabildo, ocupando a continuación el sitial. En ambos casos se entonó el correspondiente Te Deum.

Finalizada la ceremonia religiosa, el cortejo sale de la catedral para dirigirse, en el mismo orden de marcha con que habían entrado en ella, al contiguo palacio real. Únicamente la documentación de Aguilar (1793) y Ricafort (1825) aluden a las ceremonias habidas en la residencia real, tales como cumplimientos y saludos de las autoridades y personas distinguidas de la ciudad -según Aguilar, la ceremonia se repitió con su esposa-, desfile de las tropas frente a palacio y celebración de un banquete -en el caso de Ricafort, para cien cubiertos-, refresco y baile.

La última etapa de las liturgias de recepción correspondía a los regocijos oficiales. En Manila y desde 1759 éstos tenían lugar durante tres días y eran sufragados por el alcalde ordinario encargado del recibimiento en intramuros. Así, sabemos que en la entrada del gobernador Aguilar (1793) hubo durante esos tres días obsequios, comidas, cenas, músicas, refresco, baile, iluminación y representaciones teatrales. Como señala el cronista de la entrada de

En cuanto a Chile (Valenzuela Márquez, 2001: 313), su uso fue tajantemente prohibido por una real cédula de 25 de julio de 1620 .

${ }^{65}$ Valenzuela Márquez, 2001: 313. 
Ricafort (1825), el almuerzo y posterior refresco y baile pusieron fin «a todas las funciones de etiqueta y de costumbre».

Junto a estos regocijos oficiales se desplegaban, tanto el día de la entrada como durante los tres sucesivos, toda una serie de festejos «espontáneos»iguales a los que podemos ver en cualquier otro tipo de fiestas-: aplausos, gritos, vivas, todos ellos inducidos por los «ruidos» de las campanas y de las armas de fuego que disparaban algunos grupos de milicianos. Esto, más la iluminación de edificios públicos y privados, marcaban una ruptura festiva de la cotidianeidad. Es posible que tanto los regocijos oficiales como los espontáneos no tuvieran la misma espectacularidad que los celebrados en las cortes virreinales, pero sí destacaban, gracias a la presencia de las culturas asiáticas, por su exotismo y originalidad.

\section{CONCLUSIÓN}

A lo largo de estas páginas hemos podido observar cómo en la más lejana de las colonias hispanas se desarrollaba una amplia reproducción de la ceremonia de recepción de la nueva autoridad, una de las más importantes herramientas de legitimación institucional. Dicha ceremonia cumplía los mismos objetivos políticos que las llevadas a cabo en las capitales virreinales al mantener, como señala Valenzuela Márquez, los mismos pasos rituales, un posicionamiento similar de los distintos actores del poder en el espacio ceremonial (calles, plaza mayor, catedral, palacio real) y una misma voluntad para hacer del espacio público una escenografía espectacular que subyugara los sentidos.

Es cierto que la reproducción formal de la recepción no era exactamente igual que en las grandes capitales del imperio, ya que la diferencia jerárquica de la máxima autoridad filipina y los recursos económicos disponibles hacía que las fiestas en Manila fuesen tan sólo un pálido reflejo de las celebradas en México o Lima. Pero si nos alejamos de esta comparación y nos concentramos en el universo microrregional de Manila, vemos cómo la reproducción en pequeña escala del modelo general actúa dentro de la estrategia del sistema de poder: los ritos y celebraciones por la llegada de un nuevo vicario real a las Filipinas cumplían idéntica función pedagógica de unificación metafórica de los distintos componentes del sistema social en torno a la autoridad que llegaba. 
ANEXo

1. Testimonio del recibimiento del gobernador Gaspar de la Torre en Manila los días 5 y 7 de septiembre de $1739^{66}$

a) Juramento del título de presidente de la Audiencia por los oidores de ella. 5 de septiembre de 1739

Real Acuerdo extraordinario de la Audiencia de Manila, y septiembre cinco de mil setecientos treinta y nueve años. Los señores presidente y oydores de ella, estando en los reales estrados de él, por precencia de mí Juan de Monrroy, escrivano de cámara de dicha Real Audiencia y de su Real Acuerdo, haviendo sido presentada ante dichos señores la real executoria y título real de presidente de esta dicha Real Audiencia, su fecha en El Pardo a diez y ocho de marzo de mill setecientos treinta y siete, por parte del muy ilustre señor brigadier don Gaspar de la Torre, gentilhombre de la cámara de su Magestad y de su Consejo y capitán de una de las compañías del regimiento real de guardias, provisto governador y capitán general en lugar del muy ilustre señor mariscal de campo don Fernando Valdés de Tamón, del orden de Santiago, que los está sirviendo. Y haviendo yo, el presente escrivano de cámara, leydo de verbo ad verbum dicho real despacho y las diligencias que están a su continuación en las quatro foxas antecedentes a ésta, dichos señores presidente y oydores puestos en pie lo cogieron en sus manos y, en señal de obedecimiento, lo besaron y puçieron sobre sus cavezas como carta y real provisión de su rey y señor natural (que Dios guarde con augmento de mayores reynos y señoríos). Y en quanto a su cumplimiento dixeron que devían mandar y mandaron se guarde, cumpla y execute como su Magestad prebiene y manda en dicho real despacho, y que se le haga saver a dicho señor brigadier don Gaspar de la Torre, gentilhombre de la cámara de su Magestad, por uno de los señores ministros de esta Real Audiencia el que, quando fuere servido de ocurrir a aprehender possesión de dicha presidencia, está prompto este real Acuerdo para el efecto. Y por este auto assí lo proveyeron, mandaron y firmaron dichos señores, presente el abogado fiscal. Valdés. Lizenciado Fernández Thorivio. Lizenciado Costilla. Lizenciado Calderón. Lizenciado Neyra. Ante mí, Juan de Monrroy.

${ }^{66}$ Traslado auténtico de haber tomado posesión de la presidencia de Manila en las islas Filipinas el brigadier don Gaspar de la Torre. Acompaña a su carta al rey fechada en Manila a 13 de junio de 1740, AGI, Filipinas, legajo 149, n. ${ }^{\circ} 25$. 


\section{b) Juramento y toma de posesión. 7 de septiembre de 1739}

Yo, don Juan de Monrroy, secretario de cámara del rey nuestro señor que resido en la Audiencia y Real Chancillería de estas Yslas Philipinas, doy fee $\mathrm{y}$ verdadero testimonio a los señores que el presente vieren que en Acuerdo extraordinario celebrado oy siete de septiembre de mil setecientos treinta y nueve años por los señores lizenciados don Francisco Fernández Thorivio, don Francisco Costilla Borroto y don Pedro Calderón Henrríques, del Consejo de su Magestad, oydores y alcaldes del crimen de esta dicha Real Audiencia, presente el lizenciado don Domingo de Neyra, abogado fiscal que se convocó para el efecto prevenido en el real auto antecedente. Y estando dichos señores en los reales estrados, compareció el señor brigadier don Gaspar de la Torre, gentilhombre de la Cámara de su Magestad y de su Consejo, provisto governador y capitán general de estas Yslas Philipinas y presidente de esta Audiencia y Real Chancillería, para efecto de aprehender la possesión de dicha presidencia en conformidad de la executoria y título real librado en el Pardo a los diez y ocho de marzo del año pasado de mil setecientos treinta $\mathrm{y}$ siete que contiene dicho nombramiento. $\mathrm{Y}$ en conformidad de tener dicho señor hecho el juramento predefinido por ley para la serventia de dicho cargo, dichos señores en señal de possesión recivieron a dicho señor en dicha sala de Acuerdo y reales estrados de ella, y tomó en ellos el asiento y lugar preferente de presidente de esta Real Audiencia. Y luego in continenti dichos señores mandaron que a dicho señor se le entregara el real sello de su Magestad de que usa esta su Audiencia y Real Chancillería. Y en execución de esta orden compareció el theniente de chanciller acompañado de los señores lizenciados don Francisco Costilla Borroto y don Pedro Calderón Henrríques, del Consejo de su Magestad con dicho real sello de las armas de su Magestad y lo entregó a dicho señor presidente, governador y capitán general, quien le tomó en sus manos, besó y puso sobre su caveza con toda veneración, y lo entregó a dicho chanciller, ordenándole le ponga en el lugar de su destino y encargándose su fiel guardia y custodia, con lo qual quedó selebrado este acto de possesión con toda la solemnidad acostumbrada. Y dichos señores presidente y oydores mandaron se tome razón de dicho real título y estas diligencias en el libro de títulos y mercedes de esta Real Audiencia en ambas contadurías, ciudad y demás partes donde deba constar, y que se debuelva original a dicho señor brigadier presidente, governador y capitán general de esas yslas, y quedó asentado en el libro de acuerdos secretos, y se entregaron las llaves de él a dicho muy ilustre señor presidente. Y para que conste a donde convenga y deva constar doy el presente, que es fecho en esta ciudad de Manila, capital de las Yslas Philipinas, en dicho día siete de septiembre 
de mil setecientos treinta y nueve años. En testimonio de verdad lo = lugar del signo = signé, Juan de Monrroy.

c) Entrada del gobernador en la ciudad. 7 de septiembre de 1739

Yo, el capitán don Luis Santistevan, escrivano maior de esta noble ciudad de Manila, voz y voto del privilegio en su Ayuntamiento, doy fee y verdadero testimonio a los señores que el presente vieren cómo oy de la fecha por la tarde, haviendo salido el muy ilustre señor brigadier de los reales ejércitos don Gaspar de la Torre, gentilhombre de Cámara de su Magestad de la casa que le sirvió de hospedaje en el sitio del Rosario extramuros a cavallo acompañado de los señores ministros de la Real Audiencia de estas Yslas, del muy ilustre concejo, justicia y regimiento y del vezindario, llegó a la puerta comúnmente llamada la Real de esta dicha ciudad, y en el rezinto que media entre ella y el revellín o rastrillo estava preparado un tablado al que, haviéndose apeado dicho muy ilustre señor, subió con los capitulares de esta noble ciudad. Y hecha presentación del real despacho de merced en que su Magestad (que Dios guarde) se digna conferirle los empleos de governador y capitán general de estas dichas Yslas y presidente de su Real Audiencia, fue obedecido por el señor alférez real general don Domingo Antonio de Otero Vermúdez, besándole y poniéndole sobre su caveza como carta de nuestro rey y señor natural (que la divina magestad prospere con aumento de maiores reynos y señoríos), cuia diligencia conclusa se procedió por mí, dicho escrivano maior, a recivir el juramento en semejantes casos prevenido al expresado muy ilustre señor. Que haviéndole hecho en la forma acostumbrada, se pusieron en mano las llaves de la ciudad por el señor regidor y alcalde ordinario general don Matheo de Zumalde. Que admitidas por su señoría en demostración y acto de posesión, las entregó al maestre de campo del real tercio y exército de estas Yslas don Manuel de Santistevan, mandando se abriese dicha Puerta Real, lo que executada, bolviendo dicho muy ilustre señor a tomar el cavallo, entró en la ciudad acompañado del expresado concurso. Y hecha manción en la santa yglesia cathedral, donde cantó el Tedeum en acción de gracias, prosiguió hasta el real palacio de la havitación de los muy ilustres señores governadores de estas dichas Yslas, como todo más extensamente se manifiesta de dicha diligencia de pocesión constante de foxas duscientas y diez y seis a duscientas y diez y nuebe del libro corriente de Acuerdos de esta dicha noble ciudad a que me refiero. Y para que conste doy el presente en dicha ciudad de Manila en siete de septiembre de mil setecientos treinta y nuebe años. En testimonio de verdad lo signo, Luis de Santistevan. 


\section{Relato del gobernador Rafael María de Aguilar de su entrada en Manila el 29 de agosto de $1793^{67}$}

Al día siguiente de la llegada mui de mañana vino un comisionado de mi antecesor a cumplimentarme $\mathrm{y}$, al mismo efecto, una diputación de la ciudad para acordar nuestro desembarco, y seguidamente una multitud de gentes de Cavite y Manila. En efecto quedó acordado que el inmediato día nos desembarcaríamos, dando principio al fastidioso, pesado e incómodo ceremonial aprovado por la corte. Verificóse, pues, como se tenía proyectado nuestro desembarco. En Cavite dimos gracias a Dios por la felicidad de nuestro viaje, comimos en casa del castellano governador de aquella plaza y, a la tarde, con la diputación de la ciudad nos embarcamos, no para Manila por hacer malísimo tiempo para navegar en falúa, sino para Parañaque, lugar distante de la capital dos leguas. Hallí havía multitud de coches y gentes; tomamos estos carruages $\mathrm{y}$ en procesión nos dirigimos a Manila. Pero como el ceremonial dicta haya de estar el governador tres días fuera de la plaza, nos aloxaron en una linda casa situada en la isla llamada de la Combalecencia, y cátenos V.M. otra vez embarcados, pero no solos, pues los dichos tres días tubimos sin descanso la casa llena desde las 6 de la mañana hasta las doze de la noche, fuegos artificiales en el río, músicas y alboroto eterno. En la casa de la isla estaba a recibirnos la audiencia en cuerpo, ciudad, cavildo eclesiástico, consulado, diputación de comercio, capitanes de embarcaciones extrangeras fondeadas en este puerto, jueces de varios juzgados, estado mayor de la plaza y oficialidad. Por el orden con que van nombrados me fueron cumplimentando y yo, bajo el dosel, serio como un ajo; la señora sufrió en otra pieza cercada de doñas, como aquí llaman a las señoras, igual etiqueta. La que, concluida, fue puerta para dar principio a los cumplidos particulares. Y para no dilatarme inútilmente, en esta noche y días siguientes continuó este molimiento de obsequio, con bayle, música desde el amanecer hasta la media noche, comidas magníficas de 150 cubiertos, cenas soberbias, suntuosas iluminaciones con concurrencia extraordinaria, luxo general en brillantes bordados y riqueza exterior, y todo lo que V.M. quiera de magnífico. El $2^{\circ}$ día entré de particular en Manila y, privadamente, tomé en el Acuerdo posesión de la presidencia; y pasados los tres días se hizo la entrada pública.

${ }^{67}$ Inserto en la Carta de Aguilar a su amigo Jacinto Sánchez Torado, Manila 4 de diciembre de 1793, transcrita en Retana, 1906, vol. I: 431-432. Aguilar, que gobernó las Filipinas entre 1793 y 1806, partió del puerto de Pasajes el 7 de abril de 1793, llegando a la bahía de Manila a las tres de la tarde del 28 de agosto de ese mismo año. 
Esta ceremonia es inútil referirla, pues en viendo la ordenanza militar se puede inferir. Fue, según la fórmula establecida, de tropa de caballería fuera de la plaza, la de infantería dentro formando calle, saludo de artillería, etc., añadiéndose por razón de presidente de audiencia, governador político, vicepatrono, etc., la concurrencia de más cuerpos, y por la de que la inclinación de los naturales y chinos es la de espectáculos, que huviese buenos adornos en la carrera, arcos, músicas y un estrepitoso ruido de morteretes y fuegos de artificio.

En la puerta del Parián coram populo juré la defensa de la plaza e islas; en cuyo acto hubo salba y repique de campanas. Siguió la procesión a la catedral, el arzobispo me puso a su derecha, me dio posesión de la silla de vice-patrono, se cantó el Te Deum y, en el mismo orden de marcha, nos encaminamos a palacio, donde depositado bajo de dosel reciví otra descarga de arengas de arzobispo, obispo, audiencia y demás cuerpos; repitiendo con la señora, que hizo a poco rato su entrada pública, igual ceremonia.

Tres días estube preso en palacio con iguales y aun mayores formalidades que en la casa de la isla. Y abrumado de obsequios, comidas, cenas, músicas, refrescos y bailes, cumplí el término de mi arresto, empezando a disponer de mí mismo.

Estas festividades y cultos están a cargo de dos alcaldes de Manila, empleos que obtienen las principales gentes del país y se nombran cada año; la ciudad les libra dos mil pesos fuertes, que no bastan para la comida de un día, pues sólo el ramillete y repostería cuesta mucho más, de modo que estos desgraciados mortales tienen que suplir mucho, incomodarse más y ponerse a la censura del público sobre si cumplieron o no, teniendo a mayor abundamiento que moblar el palacio, la casa y la despensa del governador. Todo esto está aprobado por S.M. menos lo de adornar el palacio, por lo qual he admitido los obsequios de ley y he renunciado los de practicar, conservando sólo los muebles del Rey, que son sillas, colgaduras, cortinas, arañas y demás que de cuenta de Real Hazienda se mantienen para antecámara y salón del retrato y dosel, sala de juntas, etc. Además, no me ha venido mal el coche y 7 cavallos que da S.M. y otros agregados de cera para iluminar días de gala, colgaduras de balcones, pago de obras y reparos de palacio, etc., pues sin este auxilio no havía sueldo para casa, adornos y demás.

A los seis días de prisión empezó el teatro o, por mejor decir, siguió sus representaciones con tres días de iluminazión. ¡Cosa admirable el ver un teatro a 6 mil leguas de la metrópoli! [...] 


\section{BiBLIOGRAFÍA}

Alva Rodríguez, Inmaculada, Vida municipal en Manila (siglos XVI-XVII), Córdoba, Universidad de Córdoba, 1997.

Buzeta, Manuel (O.S.A.) y Felipe Bravo (O.S.A.), Diccionario geográfico, estadístico, histórico de las islas Filipinas, 2 vols., Madrid, Imprenta de San José de la Peña, 1850.

Díaz-Trechuelo, María Lourdes, "The role of the chinese in the Philippine domestic economy (1570-1770)", Alfonso Felix Jr. (ed.), The Chinese in the Philippines, Manila, Solidaridad Publishing House, 1966, vol. I: 175-210.

León Pinelo, Antonio de, Autos, acuerdos y decretos de gobierno del Real y Supremo Consejo de las Indias, Madrid, por Diego Díaz de la Carrera, 1658.

Mínguez, Víctor, "La fiesta política virreinal: propaganda y aculturación en el México del siglo XVII", Karl Kohut y Sonia V. Rose (eds.), La formación de la cultura virreinal. II. El siglo XVII, Madrid/Frankfurt, Iberoamericana/Vervuert, 2004: 359-374.

Moreno Garbayo, Justa, Fiestas en Manila, año 1825, Madrid, Patrimonio Nacional, 1977.

Ollé, Manel, "Interacción y conflicto en el parián de Manila", Illes i Imperis, 10-11 (Barcelona, 2008): 61-90.

Panes, Diego, Diario particular del camino que sigue un virrey de México: desde su llegada a Veracruz hasta su entrada pública en la capital [1793], Introducción de Lourdes Díaz-Trechuelo, Madrid, Centro de Estudios Históricos del Ministerio de Obras Públicas, Transportes y Medio Ambiente, 1994.

Pérez de Uriondo, Joaquín, Diario de las ocurrencias políticas y militares de la expedición que el rey nuestro señor se sirvió destinar a las Islas Filipinas, bajo las órdenes de su capitán general el excelentísimo señor D. Mariano Ricafort. Por el coronel [...], secretario de la capitanía general y gobierno de las referidas Islas Filipinas, Manila, Imp. de Sampaloc, 1825.

Pietschmann, Horst, "La corte virreinal de México en el siglo XVII en sus dimensiones jurídico-institucionales, sociales y culturales: aproximación al estado de la cuestión", Monika Bosse, Barbara Potthast y André Stoll (eds.), La creatividad femenina en el mundo barroco hispánico: María de Zayas, Isabel Rebeca Correa, Sor Juana Inés de la Cruz, Kassel, Edition Reichenberger, 1999, vol. II: 481-497.

Recopilación de leyes de los Reynos de las Indias, Madrid, por Julián de Paredes, 1681. Diversas ediciones facsimilares.

Retana, Wenceslao E., Aparato bibliográfico de la Historia general de Filipinas deducido de la colección que posee en Barcelona la Compañía General de Tabacos de dichas Islas, Madrid, Imprenta de la Sucesora de M. Minuesa de los Ríos, 1906, 3 vols. 
Rivero Rodríguez, Manuel, La edad de oro de los virreyes: el virreinato en la monarquía hispánica durante los siglos XVI y XVII, Madrid, Akal, 2011.

Ulloa, Juan, Jorge y Antonio de, Relación histórica del viaje a la América meridional, hecho de orden de S.M., para mediar algunos grados del meridiano, Madrid, por Antonio Marín, 1748. Hay edición facsímil, con introducción y edición de José P. Merino Navarro y Miguel M. Rodríguez San Vicente, Madrid, Fundación Universitaria Española, 1978, 2 vols.

Valenzuela Márquez, Jaime, Las liturgias del poder: celebraciones públicas y estrategias persuasivas en Chile colonial (1609-1709), Santiago de Chile, Centro de Investigaciones Diego Barros Arana, DIBAM, LOM Editores, 2001.

Fecha de recepción: 23 de mayo de 2013.

Fecha de envío de las modificaciones: 23 de diciembre de 2013.

Fecha de aceptación: 16 de enero de 2014.

\section{The Entry of Governors into Manila: The Ceremony and Its Costs}

The entry of the top political authorities into the territories they were to govern was celebrated with a political feast intended to secure the local subjects'loyalty to the Crown. This study examines the entry ceremonies of Manila's governors as recounted by those who lived them and assesses their costs, which amply surpassed the 1.000 pesos set as a limit in 1686.

Key words: Entry; Governor; Ceremony; Political Feast; Manila. 